\title{
The Ever-Changing Meaning of Mass Communications: A Cursory Look at a Journal's Content
}

\section{Emmanuel K Ngwainmbi*}

International Media Communication Adviser, New Markets Adviser, USA

It is our pleasure to announce that the Journal of Mass Communication and Journalism (JMCJ) has continually published since December 2011, producing six volumes, and more than three hundred articles. The first edition had six articles covering a wide range of topics in mass communication from leading scholars, such as the noted Yahya R Kamalipour [1], Michael McDevitt [2], and Vineet Kaul [3]. Since then, the journal has continued to attract contributors from some top programs in journalism, media and communications around the world: the School of Communication Studies, Ohio University; Department of Communication, University of Seville, Spain; Department of Media Studies, CMS, Bangalore, India; and the Department of political Science. University of Antwerp, Belgium, to name a few. The journal has also meticulously published material in the fields of political science, public policy, public health and other social science areas that are cousins of mass communication.

We are delighted that, despite its meager five-year existence among some 700 Open Access journals, the JMCJ has released materials submitted by scholars and researchers particularly in Japan, India, Nigeria, USA, and Italy, with the majority of articles coming from Nigeria and India so far. We encourage researchers in other regions to consider submitting their work to the JMCJ, which is reviewed by peers.

We have to keep in mind that publication of articles is based on the blind review process and a first-come, first-served basis, not on socio-political trends or themes. Thus, authors are encouraged to prepare intellectually sound papers and to carefully follow instructions provided by reviewers if they want to see their material published in the JMCJ, keeping in mind that 'Open Access' also means that all who submit can have a sense of their level of reasoning and philosophical orientation through the body of information in the article that bears their name and institutional affiliation.

Within this framework, the eight articles in Volume 6, 3 published in June 2016, cover a broad range of topics, from media politics and ethics to the never ending debate on cultural plurality and community sanity. The first paper by Andrew Ali Ibbi addresses the corrupting of pure journalism through serving of 'brown envelopes' to journalists by politicians in Nigeria. "Journalists can be spotted at the end of every media event, waiting on politicians and other rich newsmakers to give them brown envelopes, partly because "salaries are not even enough to take care of the basic needs of the journalists" as Ibbi states [4].

The second paper written by E. Ngwainmbi demonstrates how the mass media, particularly coverage by various major television news networks, is fueling global terrorism. Drawing references from live coverage of bombings in Western and developing countries that include Belgium, France, USA, and Syria, and the machinations of strategically placed terrorist groups, the paper describes the dubious role of the online and broadcast media and offers solutions to combat and eliminate global terrorism through the joint efforts of governments and the media [5].

In the third paper, Aryalof at the Kurukshetra University in Haryana, India, presents an angle of Bishnoi religion from western India and examines the Bishnoi communication theory that preaches the need for perfect life, death and enlightenment. After analyzing 29 sutras and 120 sabdas, the author finds that communication is an exchange of healthy, meaningful and perfect messages [6].

The fourth paper explores the effects of perceived price fairness on purchase intentions in Taiwan as it relates to the mobile telecommunications industry. It then offers a context for understanding the phenomenon and adoption of a suitable price policy for potential consumers, among other options for future researchers [7].

In the fifth paper titled the Transformation of the Popular Israeli: The Increasing Dominance of Israelis Originally from North Africa and the Middle East, we find a discussion of recent changes in Israeli pop culture through the lens of television. It analyzes ways in which the image of the Mizrahi Israelis, previously depicted in popular culture as "weak, unsavory, and an object of ridicule," has been transformed into "a popular, appealing character that evokes audience identification, as Yuval Karniel and Amit Lavie-Dinur put it" [8].

In the next paper reminds us of the usefulness of the internet in our daily lives by describing how massive amounts of e-services, such as banking, shopping, entertainment, communication, e-learning and others, improve the quality of life of people all over the world. While examining the role of IT experts in the creation of more innovative web services that increasingly attract more users and offer more attractive ways to improve the quality of living, Christos Kalloniatis' paper provides the privacy characteristics that must be realized when designing services for cloud users [9].

The seventh paper written by a faculty member at St. Francis College for Women in Hyderabad, India, covers the rather mundane topic of how minorities are portrayed in the soap operas in a community in India. As expected with most studies on minorities in the media run by the majority population, the analysis reveals that the portrayal of minorities in soap operas is mostly negative and stereotyped-that they are presented as criminals, terrorists or people having links with the mafia [10].

The last paper in this issue attempts to uncover perceptions of reality television in America portrayed in social media. Through a study, the author warns that viewers of reality television should not assume that such programs are unscripted and spontaneous [11].

The contributors to this issue are to be commended for contributing

*Corresponding author: Ngwainmbi EK, International Media Communication Adviser, New Markets Adviser, USA, Tel: + 1252455 2352; E-mail: engwainmbi@gmail.com

Received June 30, 2016; Accepted June 30, 2016; Published June 30, 2016

Citation: Ngwainmbi EK (2016) The Ever-Changing Meaning of Mass Communications: A Cursory Look at a Journal's Content. J Mass Communicat Journalism 6: e164. doi: 10.4172/2165-7912.1000e164

Copyright: ( 2016 Ngwainmbi EK. This is an open-access article distributed under the terms of the Creative Commons Attribution License, which permits unrestricted use, distribution, and reproduction in any medium, provided the original author and source are credited. 
Citation: Ngwainmbi EK (2016) The Ever-Changing Meaning of Mass Communications: A Cursory Look at a Journal's Content. J Mass Communicat Journalism 6: e164. doi: 10.4172/2165-7912.1000e164

Page 2 of 2

a small body of knowledge in the social sciences, and for taking the research on media, journalism, ethics, and social reality to the next level, and offering future researchers more time, space and material to hone the scant knowledge offered.

We offer future issues of the JMCJ to you, convinced that every tiny step taken forward or backward can only give the editors, technical staff and paper contributors an opportunity to strengthen their efforts and promote knowledge sharing in the academic community, and perhaps other places as well, on important subjects often neglected and not widely disseminated.

We ask that you consider accessing and/or contributing to the JMCJ. I am convinced that five years (or even the next ten years) of the continuous production of knowledge in an e-world replete with well processed, un-processed and under-processed information can easily make a product such as JMCJ more visible.

\section{References}

1. McDevitt M (2011) Journalists' Perception of a Punitive Public:Explaining the Impulse of Social Control. J Mass Communicat Journalism 1: 1.

2. Kamalipour YR (2011) Modern Technologies and Human Relations. J Mass Communicat Journalism 1: 2.
3. Kaul V (2011) Globalisation and Media. J Mass Communicat Journalism 1: 17-24.

4. Ibbi AA (2016) The Battle for Professionalism in Journalism in Nigeria amidst Unethical Practices. J Mass Communicat Journalism 6: 1-5.

5. Ngwainmbi EK (2016) The Mediatization of Violence: A Model for Utilizing Public Discourse and Networking to Counter Global Terrorism. J Mass Communicat Journalism 6: 6-13.

6. Aryal A (2016) Moksha from Communication: An Ecological Perspective of Bishnoi Religion from Western India. J Mass Communicat Journalism 6: 14-16.

7. Chang CC, Wu WT (2016) While Number Superstitions Exist: The Influence of Prices on Mobile Phone Consumers Purchase Intentions. J Mass Communicat Journalism 6: 17-21.

8. Karniel Y, Lavie-Dinur A (2016) The Transformation of the Popular Israeli: The Increasing Dominance of Israelis Originally from North Africa and the Middle East. J Mass Communicat Journalism 6: 22-28.

9. Kalloniatis C (2016) Increasing Internet Users Trust in the Cloud Computing Era: The Role of Privacy. J Mass Communicat Journalism 6: 29-33.

10. Kaluvoya A (2016) Portrayal of Minorities in Telugu Soap Operas: An Analysis on Culture and Characterization. J Mass Communicat Journalism 6: 34-37.

11. Weiland SJ, Dunbar K (2016) What's real about reality television? J Mass Communicat Journalism 6: 38-40. 